\title{
CD14 wt Allele
}

National Cancer Institute

\section{Source}

National Cancer Institute. CD14 wt Allele. NCI Thesaurus. Code C51111.

Human CD14 wild-type allele is located in the vicinity of $5 q 31.3$ and is approximately $1 \mathrm{~kb}$ in length. This allele, which encodes monocyte differentiation antigen CD14 protein, plays a role in receptor-mediated interactions and in the clearance of apoptotic cells. 